\title{
Integrated Ecological and Economic Analysis of Ranch Management Systems: An Example From South Central Florida
}

\author{
Hilary M. Swain, ${ }^{1}$ Patrick J. Bohlen, ${ }^{2}$ Kenneth L. Campbell, ${ }^{3}$ \\ Laurent O. Lollis, ${ }^{4}$ and Alan D. Steinman ${ }^{5}$
}

\begin{abstract}
Authors are ${ }^{1}$ Executive Director, Archbold Biological Station, Lake Placid, FL 33862; ${ }^{2}$ Director of Research, MacArthur Agro-ecology Research Center, Lake Placid, FL 33852; ${ }^{3}$ Professor and Associate Chair, Department of Agricultural and Biological Engineering, University of Florida, Gainesville, FL 32611; ${ }^{4}$ Ranch Manager, MacArthur Agro-ecology Research Center, Lake Placid, FL 33852; and ${ }^{5}$ Director, Annis Water Resources Institute, Grand Valley State University, Muskegon, MI 49441.
\end{abstract}

\begin{abstract}
Developing sustainable ranch management systems requires integrated research that examines interrelations among ecological and economic factors. In south central Florida, where phosphorus $(\mathrm{P})$ loading is an overriding environmental concern, we established an interdisciplinary experiment to address the effects of cattle stocking density and pasture type on P loading and other ecological and economic factors in subtropical Florida ranchlands through a partnership including ecologists, agricultural faculty, agency personnel, and producers. Here we present an overview of all project components detailed in 3 accompanying papers in this issue of Rangeland Ecology \& Management. We describe the experimental design, which included 2 replicates of 4 different cattle stocking density treatments (control, low, middle, and high $[0,15,20$, and 35 cow-calf pairs per pasture]) maintained on 8 improved summer pastures ( 20 ha each), and 8 seminative winter pastures ( $\sim 32$ ha each) from 1998 to 2003. Stocking densities did not significantly affect $P$ loads and concentrations in surface runoff, soil chemistry, or soil nematode communities, but did affect cattle production and economic performance. Cattle production was greater at the high than at the middle or low stocking density; economic performance declined significantly with decreasing stocking density (break-even was $\$ 1.89 \cdot \mathrm{kg}^{-1}$ for high and $\$ 2.66 \cdot \mathrm{kg}^{-1}$ for low density). Pasture type significantly affected environmental factors; average $\mathrm{P}$ runoff from improved summer pastures $\left(1.71 \mathrm{~kg} \mathrm{P} \cdot \mathrm{ha}^{-1} \cdot \mathrm{y}^{-1}\right)$ was much greater than from seminative winter pastures $\left(0.25 \mathrm{~kg} \mathrm{P} \cdot \mathrm{ha}^{-1} \cdot \mathrm{y}^{-1}\right)$, most likely because of past $\mathrm{P}$ fertilizer use in improved pastures. We integrate results from all the papers within the context of a conceptual model and a P budget, and emphasize that management practices targeted at specific environmental factors on beef cattle ranches, such as nutrient loading, must include consideration of economic impacts and broader ecosystem implications.
\end{abstract}

\section{Resumen}

Desarrollar sistemas sostenibles de manejo de los ranchos requiere de la investigación integrada que examine las interrelaciones entre los factores ecológicos y económicos. En el sur y centro de Florida, donde la carga de fósforo (P) es una preocupación ambiental abrumadora, establecimos un experimento interdisciplinario para estudiar los efectos de la densidad de carga animal y tipo de pradera sobre la carga de $\mathrm{P}$ y otros factores ecológicos y económicos en los ranchos subtropicales de Florida el estudio se realizó a través una sociedad que incluyó ecólogos, agrónomos, personal de las agencia y productores. Aquí presentamos detalles del diseño experimental y un punto de vista integrado de los hallazgos del proyecto. El diseño experimental incluyó dos repeticiones de cuatro diferentes tratamientos de densidades de carga animal $(0,15,20$ y 35 pares de vaca-becerro) mantenidos en 8 praderas mejoradas de verano ( $\sim 20$ ha cada una) y 8 praderas de invierno semi-nativas ( $\sim 32$ ha cada una) de 1999 al 2003 . Las densidades de carga animal no afectaron significativamente las mediciones ambientales de cargas de nutrientes y las concentraciones del escurrimiento superficial, química del suelo o comunidades de nemátodos, pero afectaron la producción animal y los aspectos económicos. La producción de ganado fue mayor en la densidad alta que en las densidades media o bajas, el comportamiento económico disminuyó significativamente con la disminución de la densidad de carga animal (el punto de equilibrio fue s $\$ 1.99 \cdot \mathrm{kg}^{-1}$ para la densidad alta y $\$ 2.96 \cdot \mathrm{kg}^{-1}$ para la baja). El tipo de pradera afectó significativamente los factores ambientales, el promedio de $\mathrm{P}\left(1.71 \mathrm{~kg} \mathrm{P} \cdot \mathrm{ha}^{-1} \cdot \mathrm{año}^{-1}\right)$ en el escurrimiento de las praderas mejoradas (verano) fue mucho mayor que el de las praderas seminativas de invierno $\left(0.25 \mathrm{~kg} \mathrm{P} \cdot \mathrm{ha}^{-1} \cdot \mathrm{año}^{-1}\right)$, muy probablemente debido al uso pasado de la fertilización con $\mathrm{P}$ en las praderas mejoradas. Estos resultados enfatizan que las practicas de manejo enfocadas a factores ambientales específicos, como las cargas de P, en los ranchos de producción de ganado para carne necesitan considerar los impactos económicos y las implicaciones a mayor escala en el ecosistema.

This paper was funded in part by US Dept of Agriculture Grants 97-35108-5125 and 2001-35211-10080, South Florida Water Management District Contracts C-8614 and C-13414, the University of Florida, and the Florida Dept of Agriculture and Consumer Services, and the Florida Dept of Environmental Protection through the US Environmental Protection Agency 319 program. This paper is contribution 95 of the MacArthur Agro-ecology Research Center, and was approved for publication as Journal Series R-10196 of the Florida Agricultural Experiment Station.

Correspondence: Patrick J. Bohlen, MacArthur Agro-ecology Research Center, 300 Buck Island Ranch Rd, Lake Placid, FL 33852. Email: pbohlen@archbold-station.org

Manuscript received 3 April 2005; manuscript accepted 22 October 2006. 
Key Words: stocking rate, stocking density, water quality, grazing management, cow-calf operations, economic performance, phosphorus, bioindicators

\section{INTRODUCTION}

Lack of information about the ecological and economic consequences of ranch management on grazing lands deprives us of a basic understanding of the effects of a widespread human intervention on the landscape. This lack of information, which is particularly acute for privately owned grazing lands, limits our ability to assess management or restoration options and limits the capacity of decision makers and the public to understand the role of grazing lands at local, regional, and global scales. An integrated approach to agroecological research in grazing lands is needed to promote ecologically and economically sustainable practices (Carroll et al. 1990; Gliessman 1990; Teague 1996).

Integrated research is necessary to explain how agricultural activities contribute to important environmental concerns, such as non-point source pollution, or can be modified to ameliorate these concerns. Agriculture is a major source of phosphorus $(\mathrm{P})$ and nitrogen $(\mathrm{N})$ inputs to aquatic ecosystems (Sharpley et al. 1994; Carpenter et al. 1998; Bennett et al. 2001). Improving water quality in impacted areas requires revised land management practices and restoration of natural hydrologic and wetland functions (Carpenter et al. 1998). However, to be successful, such revised practices or restoration must take into account the broader relationships among economic, physical, and ecological factors.

South central Florida is one region of the United States that faces major challenges in protecting water quality and wetland ecosystems in the face of encroaching development and significant agricultural production (DeAngelis et al. 1997; Harwell 1998). This region's extensive grazing lands contribute to Florida's ranking among states as 12th nationally and third east of the Mississippi River in beef calf production (US Department of Agriculture-National Agricultural Statistics Service 2006). About 1 million head, dominated by beef cow-calf units, are supported on over 2.1 million ha of pasture and rangeland, which are mostly in south central Florida, largely on privately owned lands, and geographically overlapping some of the most sensitive wetland systems in the state.

Land use changes within this ecosystem have dramatically changed the habitat characteristics and patterns of nutrient flow for uplands, marshes, and lakes resulting in increasing nutrient loads into Lake Okeechobee. This large $\left(1,732 \mathrm{~km}^{2}\right)$, shallow (mean depth, $2.7 \mathrm{~m}$ ) eutrophic lake is the main receiving water body of this region and is the heart of south Florida's water supply, providing a connection between the Kissimmee River, the Everglades, and sensitive coastal estuaries (Aumen 1995). The lake's littoral zone provides important habitat for wading birds and waterfowl (Cox et al.1994), and is a valuable fishery and important water supply for residential and agricultural users. Total P concentration in Lake Okeechobee has more than doubled since the 1970s, causing increased algal blooms and eutrophication (Steinman et al. 1999; Havens and Schelske 2001). This serious problem is being addressed by various plans to reduce nutrient inputs to the lake (South Florida Water Management District 1997, 2004a, 2004b).
Despite these considerable efforts, the $\mathrm{P}$ inputs into the lake are well above the targeted level of $140 \mathrm{Mg} \cdot \mathrm{y}^{-1}$ based on total maximum daily load (TMDL) limits established by the Florida Department of Environmental Protection.

Regulators have targeted beef cattle ranches in the Lake Okeechobee watershed to achieve a portion of the desired P load reductions. Although $\mathrm{P}$ concentrations associated with beef cow-calf ranches are low in comparison with dairy farms and other more intensive agricultural operations, these ranches occupy $51 \%$ of the Okeechobee watershed, making them a large cumulative contributor to P loads into the lake (Hiscock et al. 2003). The cattle ranching community has identified a variety of cattle best management practices (BMPs) for water quality improvements, including modified fencing, drainage, feed/water locations, and fertilization regimes, that are expected to reduce P runoff (Florida Cattlemen's Association [FCA] 1999). However, many of these BMPs have not been tested to ascertain their effectiveness. An interagency group, including the Florida Department of Agriculture and Consumer Services (FDACS), South Florida Ecosystem Restoration Working Group, and Florida Department of Environmental Protection (FDEP), has developed a voluntary water quality BMP implementation program to reduce $\mathrm{P}$ loads from agricultural operations in the Okeechobee watershed, including cow-calf operations.

One proposed BMP aimed at reducing nutrient loadings into Lake Okeechobee would require lowering stocking density on beef cow-calf operations. However, data concerning the effects of stocking density on nutrient loading at realistic field scales are limited, especially for humid tropical or subtropical systems. Most work on the effects of stocking density is in terms of rotational grazing and has focused on vegetation or cattle responses (e.g., Taylor et al. 1997; Hart et al. 1988; Heitschmidt et al. 1989; McCollum et al. 1999; Gillen et al. 2000); a limited number of studies have addressed the relationship between stocking density and water quality (Emmerich and Heitschmidt 2002; Mapfumo et al. 2002).

Integrated experimental approaches, assessing both ecological and economic responses to stocking density, are lacking. Although stipulating stocking density as a BMP is relatively easy from a regulatory perspective, it may have severe economic impacts on producers and should only be implemented if the data are there to support effectiveness. We launched a major integrated research program to examine physical, ecological, and economic responses to changes in stocking density at the MacArthur Agro-ecology Research Center (MAERC), a fullscale commercial cattle ranch in Florida. The research partners included Archbold Biological Station, the University of Florida Institute of Food and Agricultural Sciences (UF-IFAS), the South Florida Ecosystem Restoration Working Group, FCA, the US Department of Agriculture Natural Resources Conservation Service (USDA-NRCS) and Agricultural Research Service (USDA-ARS), FDACS, and FDEP. The project's core integrated components included physical factors, forage analysis, soil fauna, soil processes, nutrient cycling, hydrological flows, wildlife populations, animal production, and economics. 
Table 1. Densities (control [no cattle], low, middle, and high) and animal-unit days for summer pastures $\mathbf{S 1 - S 8}$, and winter pastures W1-W8 over the experiment, 1998-2003.

\begin{tabular}{|c|c|c|c|c|c|}
\hline Pasture & $\begin{array}{l}\text { Area } \\
\text { (ha) }\end{array}$ & Stock density & $\begin{array}{l}\text { Animal } \\
\text { units }\end{array}$ & $\begin{array}{l}\text { Area } \cdot \text { animal } \\
\text { unit }^{-1} \text { (ha) }\end{array}$ & $\begin{array}{c}\text { Total } \\
\text { animal-unit days }\end{array}$ \\
\hline S1 & 22.04 & Control & 0 & 0 & 0 \\
\hline S2 & 19.01 & Middle & 20 & 0.95 & 20500 \\
\hline S3 & 20.42 & High & 35 & 0.58 & 35875 \\
\hline S4 & 20.49 & Low & 15 & 1.37 & 15450 \\
\hline S5 & 20.95 & High & 35 & 0.60 & 36050 \\
\hline S6 & 19.49 & Low & 15 & 1.30 & 15450 \\
\hline S7 & 19.22 & Middle & 20 & 0.96 & 20620 \\
\hline S8 & 20.30 & Control & 0 & 0 & 0 \\
\hline W1 & 33.23 & Low & 15 & 2.22 & 10455 \\
\hline W2 & 31.30 & Middle & 20 & 1.56 & 13900 \\
\hline W3 & 33.64 & High & 35 & 0.96 & 24535 \\
\hline W4 & 34.12 & Control & 0 & 0 & 0 \\
\hline W5 & 32.31 & High & 35 & 0.92 & 24395 \\
\hline W6 & 32.08 & Low & 15 & 2.14 & 10455 \\
\hline W7 & 30.24 & Control & 0 & 0 & 0 \\
\hline W8 & 30.27 & Middle & 20 & 1.51 & 13940 \\
\hline
\end{tabular}

The collaborating partners posed the following 3 questions: 1) Does cattle stocking density have a significant effect on nutrient loadings, specifically $P$, in surface waters flowing off grazing lands?; 2) To what extent might stocking density affect cattle production and the producer's financial returns?; and 3) How may cattle stocking density affect other environmental factors of interest to the public, such as measures of biodiversity? In this paper we present the project rationale and overview for all components detailed in the 3 accompanying papers in this issue of Rangeland Ecology \& Management (Arthington et al. 2007; Capece et al. 2007; McSorley and Tanner 2007). We describe the experimental design, site description, and agricultural operations for the experiment from 1998 to 2003. Finally, we integrate results from all the papers within the context of a conceptual model and a $\mathrm{P}$ budget, and emphasize the relevance of the results for sustainable management of ranch systems regionally.

\section{EXPERIMENTAL DESIGN AND METHODS}

\section{Study Site}

The study was conducted at MAERC, a 4,290-ha cattle ranch owned by the John D. and Catherine T. MacArthur Foundation and leased to Archbold Biological Station. The ranch is managed at commercial production levels ( 3,000 cows) for research purposes, providing staff and visiting scientists an opportunity to measure and monitor ecological effects of agricultural practices at real-world scales of space and numbers (Swain 1998). The ranch is located in Highlands County, south central Florida, and is part of the Indian Prairie basin of the Lake Okeechobee watershed. Like most ranches in the region, MAERC has little topography, poor natural drainage, a high wet-season groundwater table, and extensive pastures interspersed with seasonal wetlands and cabbage palm and oak hammocks. The climate includes a warm dry season from

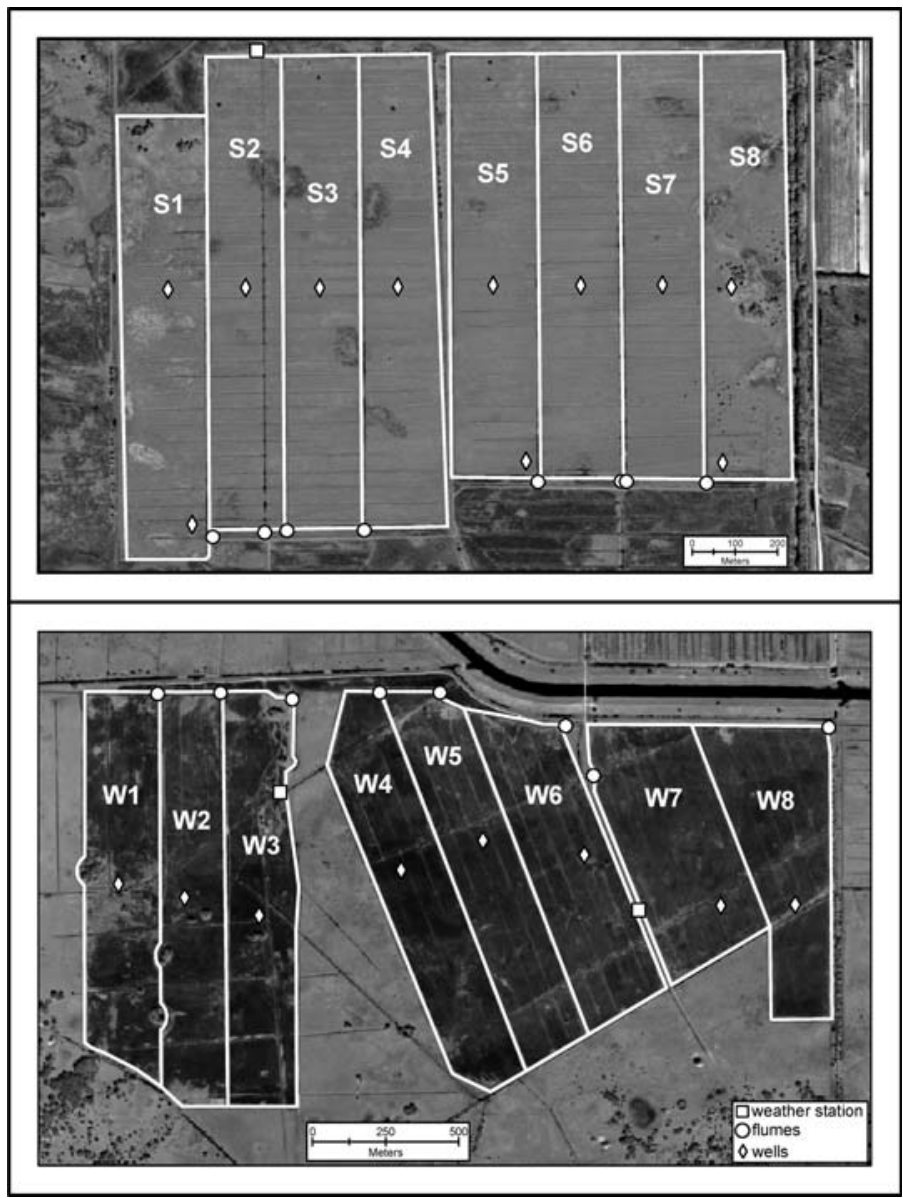

Figure 1. Aerial images of pastures with an overlay of pasture boundaries, and locations of flumes, weather stations, and groundwater wells. Spatial data recorded using a Trimble Pro XR GPS Unit. Top, Summer pastures S1-S8. Bottom, Winter pastures W1-W8.

November through May and a hot, wet season from June through October, with annual average rainfall of $132 \mathrm{~cm}, 75 \%$ of which typically falls in the wet season (meteorological data for the experimental period are given in Capece et al. 2007). Two study areas on MAERC were selected for this experiment to represent typical regional pasture types, improved and seminative (sometimes also referred to as "unimproved") pastures, which are referred to here also as summer (improved) and winter (seminative) pastures, because of differences in the main grazing season for these 2 types of pasture.

\section{Experimental Design}

Four experimental stocking densities (control [no cattle], low, middle, and high; Table 1) were selected based on input from FCA and UF-IFAS (average regional stocking densities are 1 animal unit per 1.42 ha; Gornak and Zhang 1999). There were 2 replicates of each stocking density in each pasture type, improved (summer) and seminative (winter) pastures, for a total of 16 pastures (Table 1 ).

Construction of the experimental pastures occurred from 1996 to 1998. Trapezoidal flumes were installed between winter 1997 and summer 1998 to sample and monitor all the surface runoff, collected via ditches, for each pasture (Figs. 1a and $1 \mathrm{~b}$; Capece et al. 2007). 


\section{Improved Pastures-Summer Pastures}

A 162 -ha improved pasture study area (lat $27^{\circ} 8.7^{\prime} \mathrm{N}$, long $\left.81^{\circ} 10.6^{\prime} \mathrm{W}\right)$ was subdivided using fences in $1996-1998$, into 8 approximately 20 -ha experimental pastures, hereafter referred to as summer pastures (S1-S8) (Fig. 1a). The 4 stocking densities were applied in a randomized design to the 8 pastures (Table 1) with the exception of the control treatment, which was applied to the 2 "outside" summer pastures S1 and S8 (Fig. 1a), because they had more natural shade than S2-S7. The area was ditched in the late 1960s or early 1970s, and used since then as summer grazing for beef cow-calf pairs. Vegetation surveys were conducted pretreatment. The summer pastures were primarily Bahia grass (Paspalum notatum Flüggé), but included scattered wetlands, nearly all of which were ditched (Fig. 1a). Wetlands were composed of grasses, sedges, and miscellaneous wetland species, with dominants including big carpetgrass (Axonopus furcatus Flüggé Hitchc.), maidencane (Panicum hemitomon Schult.), soft rush (Juncus effusus L.), yellow-eyed grass (Xyris sp.) and pickerelweed (Pontederia cordata L.); some wetlands had sawgrass (Cladium jamaicense Crantz) as a dominant species. Small cabbage palm (Sabal palmetto [Walt.] Lodd. ex J.A. and J.H. Schultes) hammocks were located in S1 and S8. Pasture elevation was 7.9-8.5 m, sloping gradually to the southeast and draining through a series of ditches into the Harney Pond Canal to the south. From the early 1970s until 1987 this area was fertilized annually with UF-IFAS-recommended amounts of nitrogen, $\mathrm{P}$, and potassium (most likely $56 \mathrm{~kg} \mathrm{~N} \cdot \mathrm{ha}^{-1}$ as $\mathrm{NH}_{4} \mathrm{SO}_{4}$ or $\mathrm{NH}_{4} \mathrm{NO}_{3}$, and $34-90$ $\mathrm{kg}$ of $\mathrm{P}_{2} \mathrm{O}_{5}$ and $\mathrm{K}_{2} \mathrm{O} \cdot \mathrm{ha}^{-1}$; F. Pate, personal communication, October 2003) and then from 1987 until 1995 received only N at $56 \mathrm{~kg} \cdot \mathrm{ha}^{-1}$, applied between March and May, usually annually.

Runoff from the summer pastures drained from north to south. Each summer pasture was surrounded by a small berm ( $4 \mathrm{~m}$ wide, $0.5 \mathrm{~m}$ above grade). The original east-west lateral drainage ditches, spaced approximately every $30 \mathrm{~m}$, were connected to existing or new north-south ditches routing surface runoff through the flume at the south end of each pasture. Flume elevation was set at $7.99 \mathrm{~m}$ National Geodetic Vertical Datum (NGVD). Access for cattle work, minerals, and feed was through the north end of the pastures. Water tanks and shade were placed at the north end of each stocked pasture (S2-S7).

A 0.5 -ha resolution soil survey conducted by the USDANRCS in June 1997 showed 4 soil series at the summer pastures sites; $90.7 \%$ of the area was Felda fine sand, a sandy or loamy, siliceous, and hyperthermic alfisol. A small portion $(1.6 \%$ of area) of the Felda soils was overlain by a thin layer $(2.5-15 \mathrm{~cm})$ of muck. True muck soils present were Tequesta $(8.8 \%)$ and Gator $(0.4 \%)$; the Tequesta depressions had about $20-25 \mathrm{~cm}$ of muck with an argillic layer (Bt/clay enriched layer) $50-130 \mathrm{~cm}$ below the surface. Bradenton fine sand occurred in very small amounts $(0.2 \%)$ under cabbage palm hammocks. There was no significant difference among the summer pastures in terms of major soil series (muck or muck layer vs. nonmuck soils) $\left(\chi^{2}=13.81, P>0.05\right)$. Wetland soils in the summer pastures accounted for $9.2 \%$ of the total pasture area, with S1 and S8 having the highest percent cover of wetlands, although the proportion of wetland soils vs. nonwetland soils did not differ significantly among pastures S1-S8 $\left(\chi^{2}=6.39, P>0.05\right)$.

\section{Seminative Pastures-Winter Pastures}

A 260 -ha seminative pasture study area (lat $27^{\circ} 7.9^{\prime} \mathrm{N}$, long $81^{\circ} 12.3^{\prime} \mathrm{W}$ ) was subdivided using fences in $1996-1998$, into 8 approximately 32-ha experimental pastures, hereafter referred to as winter pastures (W1-W8) (Fig. 1b). The 4 stocking densities were applied in a randomized design to the 8 pastures (Table 1) with the exception that, at the outset of the experiment, W4 (originally designated for a high-density treatment) was swapped with W1 (originally designated as a control), because the solar well pump was unable to supply sufficient drinking water to W4. The winter pastures were primarily Bahia grass but were also vegetated with carpetgrass, sedges (Cyperaceae spp.), field paspalum (Paspalum leave Michx.), and bunchgrasses such as broomsedge (Andropogon virginicus L.) and bushy bluestem (Andropogon glomeratus [Walt] B.S.P). Interspersed throughout the winter pastures were many seasonal wetlands, nearly all within $30 \mathrm{~m}$ of existing ditches, composed primarily of grasses, sedges, and miscellaneous wetland species, with dominants including carpetgrass, maidencane, redtop panicum (Panicum rigidulum Bosc ex Nees), hat pins (Eriocaulum sp.), yellow-eyed grass, and with less pickerelweed and soft rush than in the improved pastures. Cabbage palm hammocks introduced natural shade into the western third of this pasture array (Fig. 1b). These winter pastures were less intensively drained than the summer pastures, and were regularly flooded or had saturated soils during the wet season. This area was used for many years as winter grazing. Our understanding is that this area has never been fertilized (D. Childs and D. Durrance, previous ranch manager and landowner, personal communication, March 2003).

The winter pastures were at an elevation of $\sim 8.2$ to $8.8 \mathrm{~m}$ and drained to the north. Existing and new collecting ditches in these pastures routed surface runoff through a flume at the north end of each pasture and, from there, it flowed through a main ditch into the Harney Pond Canal. Flume elevation was set at $8.08 \mathrm{~m}$ NGVD. Cattle obtained water from 2 solarpowered groundwater wells, with storage tanks and gravity-fed lines to the south end of individual pastures.

Soils series differed considerably between summer and winter pastures. In the winter pastures, 5 soil series were mapped; $79.5 \%$ of the area was Pineda fine sand, a sandy or loamy, siliceous, and hyperthermic alfisol similar to the Felda sands in the summer pastures. However in the winter pastures a large proportion $(69.0 \%)$ of the sandy Pineda soils was overlain by a thin layer $(2.5-15 \mathrm{~cm})$ of muck. Typical muck soils were also present in winter pastures, including Tequesta $(3.9 \%)$ and Gator $(0.2 \%)$; the Tequesta depressions had the same structure as in the summer pastures. Bradenton fine sand occurred in very small amounts $(0.4 \%)$ under cabbage palm hammocks. The proportion of muck or muck layer vs. nonmuck soils varied among the winter pastures W1-W8 $\left(\chi^{2}=40.77, P<0.001\right)$; however, the proportion of wetland soils $(4.1 \%$ of W1-W8) vs. nonwetland soils was more evenly distributed than in the summer pastures, and did not differ among winter pastures $\left(\chi^{2}=2.94, P>0.95\right)$.

\section{Pretreatment Pasture Comparisons}

Analysis of vegetation data (excluding wetlands) collected in a general survey of the 16 pastures prior to the start of the 
Table 2. Percentage of vegetation cover on summer pastures and winter pastures in 1995. $F$ and $P$ values from a nested analysis of variance of percentage of cover for each species among pastures, split for summer vs. winter pastures, $\mathrm{df}=7$. Bold indicates significant differences among pastures S1-S8, or W1-W8.

\begin{tabular}{|c|c|c|c|c|c|c|c|c|c|c|c|}
\hline Scientific name & Common name & S1 & S2 & S3 & S4 & S5 & S6 & S7 & S8 & $\mathrm{F}$ & $P$ \\
\hline Paspalum notatum Flüggé & Bahia grass & $87 \%$ & $76 \%$ & $88 \%$ & $93 \%$ & $84 \%$ & $87 \%$ & $63 \%$ & $78 \%$ & 0.94 & 0.482 \\
\hline Axonopus furcatus (Flüggé) Hitchc. & carpetgrass & $11 \%$ & $3 \%$ & $10 \%$ & $1 \%$ & & $7 \%$ & $29 \%$ & $17 \%$ & 2.50 & 0.024 \\
\hline Setaria parviflora (Poir.) Kerguélen & foxtail & & $9 \%$ & & & & & $3 \%$ & & 1.68 & 0.130 \\
\hline Cynodon dactylon (L.) Pers. & Bermuda grass & $2 \%$ & $7 \%$ & & & & & & & 0.88 & 0.525 \\
\hline Paspalum dilatatum Poir. & dallis grass & & & & & $9 \%$ & & & & 0.92 & 0.495 \\
\hline Centella asiatica (L.) Urban & centella & & $1 \%$ & & $1 \%$ & $2 \%$ & & $1 \%$ & $2 \%$ & 1.38 & 0.231 \\
\hline Sporobolus indicus (L.) R.Br. & smut grass & & $4 \%$ & & & & & $2 \%$ & $1 \%$ & 2.12 & 0.054 \\
\hline \multicolumn{12}{|l|}{ Andropogon glomeratus (Walter) } \\
\hline Britton et al. & bluestem & & & $2 \%$ & $1 \%$ & $2 \%$ & $1 \%$ & & & 0.86 & 0.544 \\
\hline Paspalum urvillei Steud. & vasey grass & & & & $1 \%$ & $2 \%$ & $2 \%$ & & & 1.04 & 0.415 \\
\hline Juncus effusus L. & softrush & & & & $2 \%$ & & $1 \%$ & $1 \%$ & & 0.73 & 0.649 \\
\hline Cyperaceae spp. & sedges & & & & $1 \%$ & $1 \%$ & & & $1 \%$ & 0.76 & 0.625 \\
\hline Eupatorium capillifolium Lam. & dog fennel & & & & & & $2 \%$ & & & 1.00 & 0.440 \\
\hline Phyla nodiflora (L.) Greene & lippia & & & & & & & $1 \%$ & & 1.00 & 0.440 \\
\hline Hydrocotyle umbellata L. & pennywort & & & & & & & & $1 \%$ & 1.00 & 0.440 \\
\hline \multirow[t]{2}{*}{ Polygonum sp. } & smartweed & & & & $<1 \%$ & & & & & 1.00 & 0.440 \\
\hline & & W1 & W2 & W3 & W4 & W5 & W6 & W7 & W8 & $\mathrm{F}$ & $P$ \\
\hline Paspalum notatum Flüggé & Bahia grass & $78 \%$ & $32 \%$ & $79 \%$ & $24 \%$ & $16 \%$ & $18 \%$ & $52 \%$ & $38 \%$ & 4.50 & $<0.001$ \\
\hline Axonopus furcatus (Flüggé) Hitchc. & carpetgrass & & $3 \%$ & & $33 \%$ & $36 \%$ & $26 \%$ & $20 \%$ & $6 \%$ & 3.51 & 0.003 \\
\hline Andropogon virginicus $\mathrm{L}$. & broomsedge & $9 \%$ & $24 \%$ & $9 \%$ & & $20 \%$ & $48 \%$ & & & 3.13 & 0.007 \\
\hline Cyperaceae spp. & sedges & $3 \%$ & $10 \%$ & $4 \%$ & $6 \%$ & $3 \%$ & $2 \%$ & $12 \%$ & $40 \%$ & 4.86 & $<0.001$ \\
\hline \multicolumn{12}{|l|}{ Andropogon glomeratus (Walter) } \\
\hline Britton et al. & bluestem & & $3 \%$ & $3 \%$ & $8 \%$ & $14 \%$ & $2 \%$ & $17 \%$ & $13 \%$ & 3.79 & 0.002 \\
\hline Paspalum laeve Michx. & field paspalum & & $23 \%$ & $1 \%$ & $20 \%$ & $9 \%$ & $4 \%$ & & & 2.60 & 0.020 \\
\hline Oldenlandia uniflora L. & hedyotis & $4 \%$ & & $1 \%$ & $7 \%$ & & & & & 1.62 & 0.146 \\
\hline Axonopus furcatus (Flüggé) Hitchc. & big carpetgrass & & & $3 \%$ & & $2 \%$ & & & & 1.44 & 0.207 \\
\hline Setaria parviflora (Poir.) Kerguélen & foxtail & $3 \%$ & & & & & & & & 0.93 & 0.491 \\
\hline Eleocharis spp. & spikerush & $2 \%$ & $1 \%$ & & & & & & & 0.85 & 0.552 \\
\hline Centella asiatica (L.) Urb. & centella & $1 \%$ & $1 \%$ & & $1 \%$ & & & & & 0.71 & 0.662 \\
\hline Panicum rigidulum Bosc ex Nees & redtop panicum & & & & & & & & $3 \%$ & 3.08 & 0.008 \\
\hline Bidens alba (L.) DC. & beggarticks & & $1 \%$ & & & & & & & 1.08 & 0.387 \\
\hline Eupatorium capillifolium (Lam.) Small & dog fennel & & & & & $1 \%$ & & & & 0.93 & 0.491 \\
\hline
\end{tabular}

experiment (Table 2), showed that the percentage of cover of 6 taxa (Bahia grass, carpetgrass, broomsedge, sedge species, smut grass [Sporobolus indicus $\{$ L. $\}$ R.Br.], and redtop panicum) accounted for most of the difference between the vegetative community in the summer and winter pastures (discriminant analysis, Wilks' lambda $=0.550, \mathrm{df}=1, P<0.001$, SPSS Version 11; all nonnormal data were log transformed). Vegetation in S1-S8, largely dominated by Bahia grass $(\bar{x}=82 \%$ cover) only differed among pastures in the percent of carpetgrass and smutgrass (a non-native invasive forage grass) (Table 2). In contrast, the winter pastures, which had less Bahia grass $(\bar{x}=42 \%$ cover $)$, were more species rich, and differed among pastures in the percent of Bahia, carpetgrass, broomsedge, sedge species, bluestem, field paspalum, and redtop panicum (Table 2). Prior to the experimental treatments, plant biomass, forage production, and forage utilization showed seasonal trends and varied between summer and winter pastures (Arthington et al. 2007).
Soil P levels in winter pastures were measured pretreatment in 1998, and in 2000 and 2003 (details in Capece et al. 2007). Soil types differed between the 2 pasture types (see above), but did not vary among pastures within pasture types. The soil $\mathrm{P}$ levels in summer pastures were significantly higher than those in winter pastures, both before and during experimental treatments (Capece et al. 2007).

\section{Pasture Management}

Pasture management practices were standard across all 16 pastures and similar to practices elsewhere on MAERC. Prescribed burning was conducted in the winter pastures at the start of the experiment (November-December 1998), summer pastures were burned February 1999. Accidental fires occurred in W6 and W7 in March and April 2000. Winter pastures had prescribed burns again in February 2002, and summer pastures in April 2002. Nitrogen fertilizer was applied as ammonium nitrate or other commercial mix at $56 \mathrm{~kg} \mathrm{~N} \cdot \mathrm{ha}^{-1}$ 


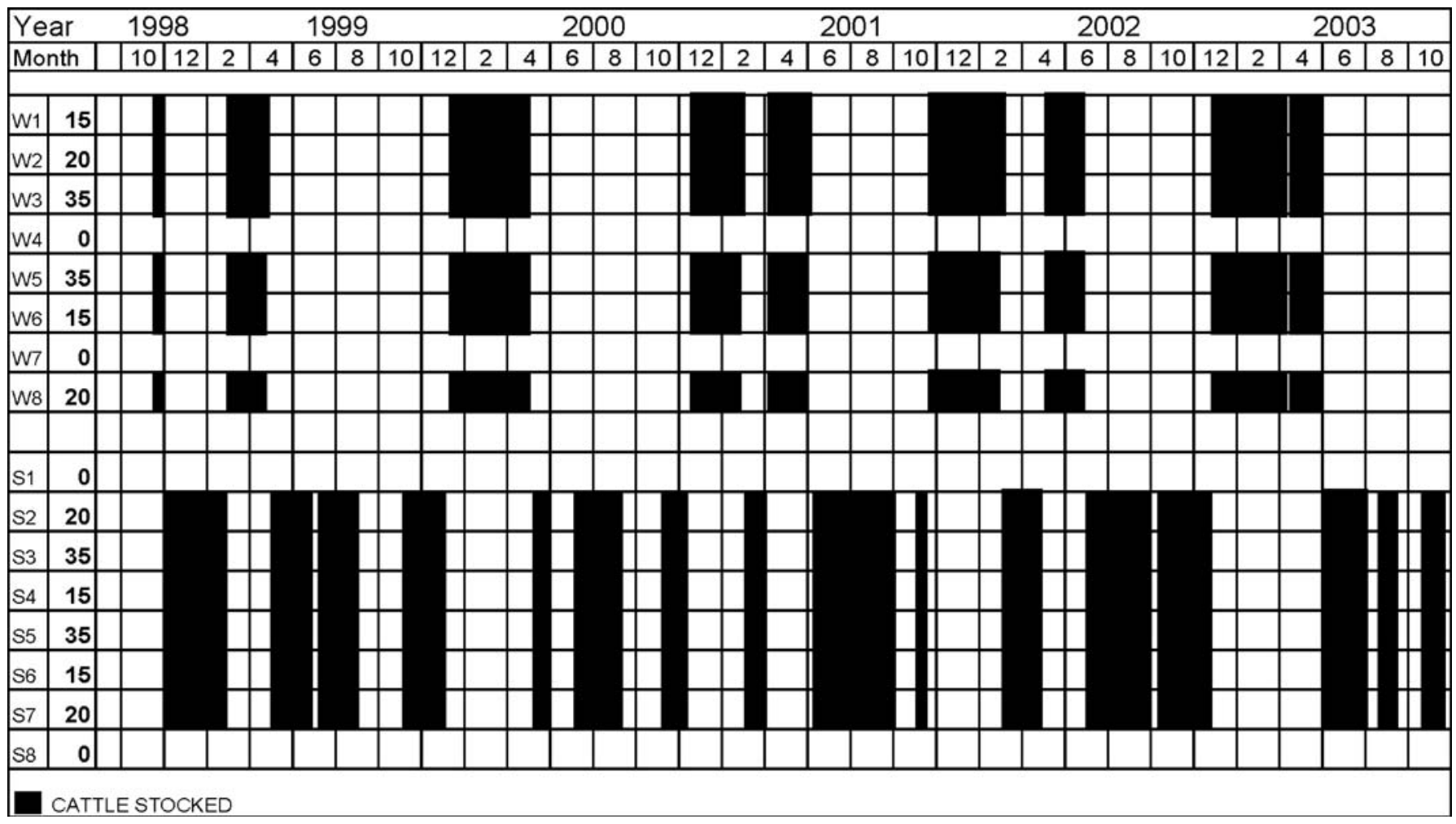

Figure 2. Cattle herd movements between summer pastures S1-S8 and winter pastures W1-W8, 1998-2003.

to the summer pastures from March to May in 2000, 2001, and 2003. Summer pastures were mowed for brush control between September and November in 1998 and 2000, and spot-mowed in 2002. Dog fennel (Eupatorium capillifolium Lam.) was treated in the summer pastures from May to July in 2001, 2002, and 2003, with WEEDMASTER $®$ (mixture of dimethylamine salts of dicamba and $2,4-\mathrm{D}$ ) at $4.6 \mathrm{~L} \cdot \mathrm{ha}^{-1}$ plus $7.5 \mathrm{~mL} \cdot \mathrm{L}^{-1}$ of nonionic surfactant. Summer pastures were aerated August-October 2003. The ditches downstream from the flumes in the summer and winter pastures were cleaned out in approximately May or June annually to minimize blockage and ensure flow.

\section{Cattle Herd Management}

The cattle stocking treatments started on 10 October 1998. Each of the 6 experimental cattle "herds" were labeled with different-colored ear tags and were rotated between winter and summer pastures until the experiment ended on 23 October 2003 (Fig. 2). Cows spent the majority of the time during MayOctober in the summer pastures, and most of the time during November-April in the winter pastures (Fig. 2). Movements varied from this schedule depending on shipping dates of calves, prescribed burns, and occasionally the availability of drinking water. Cattle grazed continuously, and were provided with supplementary feed in the form of urea-fortified liquid molasses (16\% crude protein; as-fed basis) in the winter months (November-March), and minerals (PDQ7; Lakeland Animal Nutrition, Lakeland, FL) year-round. Molasses and minerals were supplied in open tanks and mineral boxes; the locations were moved regularly, but were generally at the north end of pastures. The total annual intake for each cow and calf pair averaged $310 \mathrm{~kg}$ and $11.5 \mathrm{~kg}$ of molasses and mineral supplement, respectively.

Cattle in the experimental pastures were managed in the same manner and on the same schedule as the commercial herd at MAERC. The 140 cows in the experimental herds were 4- to 8 -year-old Brahman-cross cows with a body condition at the outset of 5, selected from the ranch herd. All dead cows and calves, or cows without calves, were replaced with an equivalent cow or cow-calf pair at the first available time. On one occasion (August-September 2000), cattle other than the experimental herds were placed in summer pastures; 3 herds of 15 bulls each were rotated among S2-S7. Standard pregnancy checking, deworming, Vibriosis and Leptospirosis vaccinations, Trichomoniasis testing, and external parasite control were conducted annually in September. Calves were dewormed, castrated, dehorned, implanted, and branded in FebruaryMarch annually. Cows were scored for body condition each time they were worked. Calves were separated from the cows and weighed before shipping in late August-September annually; cows returned to the experimental pastures in late September-October, 2-4 weeks after separation from calves, to allow them to settle. One bull was placed into each pasture with cows for approximately 4-5 months each year (January or February to June).

Cattle production data (including inventories, pregnancy checking, and weaned calves) and costs (including feed and minerals use, veterinary care, and labor) were collected yearround for each of the herds in the experimental pastures, as well as for the entire ranch herd. Financial performance data such as depreciation schedules and income statements were produced annually for the entire herd. Production and economic data 
were compiled by Gene Lollis at MAERC using the standardized performance analysis program (McGrann et al. 2001) to calculate, for example, economic return and economic breakeven price per breeding cow. These economic analyses are presented in Arthington et al. 2007.

\section{OVERVIEW OF PROJECT FINDINGS}

Here we examine the 3 questions outlined in the introduction within the framework of a simple conceptual model of the relationships among the various inputs, internal transfers, and outputs involved in the cattle operation on a typical Florida cow-calf ranch (Fig. 3). We consider cattle as the center of this conceptual model, recognizing this may also imply factors beyond cattle stocking density, such as spatial distribution, health, and animal condition. In the model we show 3 outputs or potential outcomes-nutrient loadings, financial returns, and indicators of biodiversity-that are potentially influenced by cattle stocking density or by other management practices or biophysical features of a ranch operation. The challenge is to find an acceptable balance between reducing nutrients of regulatory concern while maintaining financial viability for the producer and retaining ecological values such as biodiversity.

Three types of inputs set the stage for the annual management decisions ranchers make, and the management practices they employ (Fig. 3). First, antecedent conditions such as the status of pastures or cattle condition going into the breeding cycle affects annual management decisions concerning the cow herd, such as the amount of feed supplementation needed. Second, external market conditions, particularly average pay weight for steers and heifers (which ranged from a low of $\$ 1.65 \cdot \mathrm{kg}^{-1}\left[\$ 0.75 \cdot \mathrm{lbs}^{-1}\right]$ in 1999 to a high of $\$ 2.23 \cdot \mathrm{kg}^{-1}$ $\left[\$ 1.01 \cdot \mathrm{lbs}^{-1}\right]$ in 2001), as well as costs for major items, such as fertilizer, supplementary feed, and veterinary costs, may influence the degree to which a rancher can invest in costly annual inputs (Arthington et al. 2007). Third, the regulatory environment may limit the extent to which the producer is able to apply certain inputs; for example, to receive a presumption of compliance with water quality standards, ranchers in the Okeechobee watershed are now required to have nutrient management plans, which may limit the amount of $\mathrm{P}$ fertilizer they can apply. These socioeconomic inputs interact with abiotic factors, physical inputs such as rainfall and fire. For example, drought, flooding, or winter freezes all reduced forage availability or quality over the course of this experiment, and increased demands for, and inputs of, supplementary feed, which varied in cost from a low of $\$ 28.58$ per head in 1999 to a high of $\$ 65.68$ in 2003 (Arthington et al. 2007).

In comparison to physical factors and ranch practices, cattle stocking density had a significant impact on energy flow and transfers in the forage component of the conceptual model but had little impact on soil nutrient pools (Fig. 3). At the stocking densities studied, average forage utilization overall was low $(\sim 30 \%)$ but at the high stocking density there was greater forage utilization and significantly less available forage at the end of the grazing cycles when compared to the middle and low stocking densities, neither of which differed substantially from control pastures (Arthington et al. 2007). Although soil nutrient levels, especially $\mathrm{P}$, varied considerably among pas-

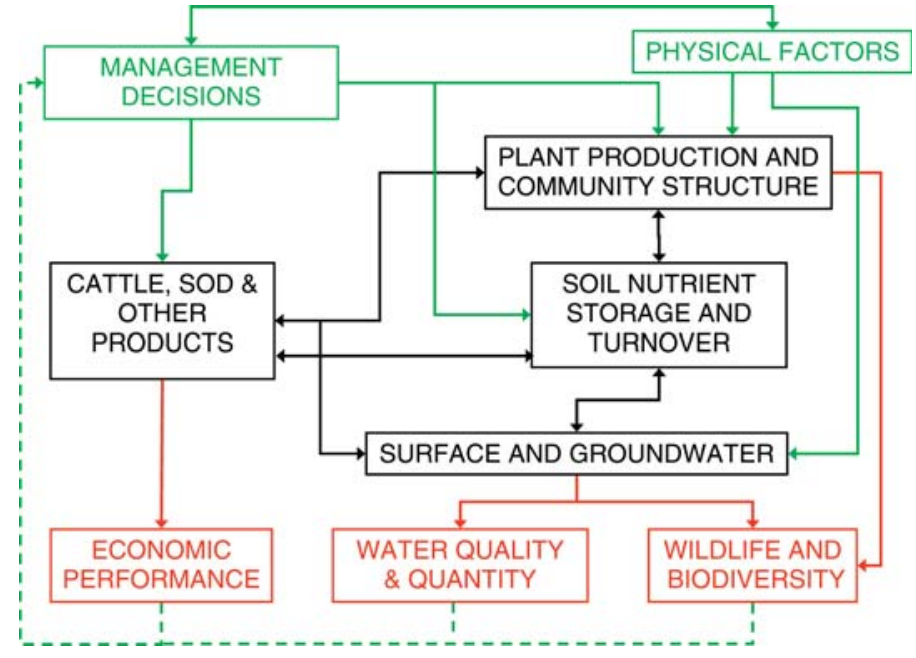

Figure 3. Conceptual model showing the relationships among inputs, the measured components of the stocking density experiment, and outputs, and illustrating the integrated and interdisciplinary nature of the study's approach. Green boxes represent the external factors such as management decisions, which are influenced by a variety of socioeconomic factors, and physical factors, such as annual variation in rainfall. Black boxes represent interrelationships among the main components of the ranch ecosystem. Red boxes represent the 3 main outputs or ecosystem services of interest to the rancher and to society. See text for discussion.

tures, levels were not correlated with cattle stocking density. However, soil $\mathrm{P}$ concentrations were about 1.4 times greater in the summer pastures than in winter pastures, suggesting the cumulative impact of previous applications of $\mathrm{P}$ fertilization had a far greater effect on soil nutrient levels than did stocking densities (Capece et al. 2007).

Higher cattle stocking densities were not strongly related to nutrient loadings and indicators of biodiversity (Fig. 3). Cattle stocking density did not affect overall soil P levels or P loadings or concentrations in surface runoff (Capece et al. 2007). Rather, the 2 factors that account for much of the variation in $\mathrm{P}$ loadings in surface water leaving the pastures were pasture type (summer improved vs. winter seminative) and annual rainfall. Differences between the 2 pasture types resulted in 7.0-fold greater P loadings from improved (summer) pastures vs. seminative (winter) pastures (Capece et al. 2007). Annual rainfall ranged from 74.3 to $155.9 \mathrm{~cm}$ and nutrient loads in surface runoff were greater in years of higher rainfall. Stocking density also had little effect on soil nematode communities, which were measured to assess biodiversity impacts (McSorley and Tanner 2007), and apparently had little effect on the bird communities in the pastures (Tanner, unpublished data, 1998-2003). However, as with water quality, there were significant differences in nematode and bird communities between pasture types, although not as great as the differences in soil and water chemistry.

Although stocking density did not affect nutrient loadings or measured bioindicators, it did have a large impact on production and financial returns. Overall production was higher at higher densities, but was not associated with decreasing cow body condition (Arthington et al. 2007). However, per-unit production costs increased significantly with decreasing stocking density, mainly because fixed costs of production remained 
constant irrespective of herd size. When data from the experimental pastures were applied ranch-wide using actual costs of production and realistic assumptions for cattle performance, break-even prices rose from $\$ 1.99 \cdot \mathrm{kg}^{-1}$ at the high stocking density to $\$ 2.66 \cdot \mathrm{kg}^{-1}$ at the low stocking density (Arthington et al. 2007).

The project results indicate that adjustments in stocking rate at the levels examined in our experiment would not be an effective approach to reducing nutrient runoff for cattle ranches in south and central Florida, especially given the large economic burden that ranchers would bear if they significantly reduced current stocking rates. This finding seems to hold true for a wide range of environmental conditions and external market conditions. It is possible that there are situations within the watershed where reducing stocking rates on pastures that are overstocked or stocked at a higher density than our highest stocking density could result in lower nutrient loads in surface runoff. However, our stocking densities were specifically chosen to represent regional averages and it appears unlikely that stocking rate adjustments within the range that we examined would lead to significant short-term reduction in nutrient loadings. In the long term, minimizing net $\mathrm{P}$ imports in fertilizer and supplementary feed, managing water to reduce $\mathrm{P}$ export in surface flow, and optimizing $\mathrm{P}$ export in calves and other products (e.g., sod) may be more effective than reducing stocking densities as a means to decrease nutrient loadings in surface runoff. P budgeting of ranch operations is an important step toward identifying opportunities for reducing $\mathrm{P}$ inputs, increasing outputs, and understanding constraints on the overall $\mathrm{P}$ budget.

\section{P Import-Export Budgets for Ranch Systems}

Analysis of $\mathrm{P}$ inflows to and outflows from a ranch indicates whether current operations are contributing to net $\mathrm{P}$ accumulation or export from the system. There continues to be a significant net import of $\mathrm{P}$ to improved cattle pastures in the Lake Okeechobee watershed, although the net imports have declined over the past 10-15 years, in part because of reduced $\mathrm{P}$ fertilizer use in the region (Hiscock et al. 2003). Net P imports per hectare are much greater for more intensive agricultural land uses, such as dairy or vegetable crops, but the large acreage of improved pasture contributes to the large net import for this land use. Improved pasture has higher net imports than unimproved pasture or rangeland because the latter 2 land uses do not receive $\mathrm{P}$ fertilizer, whereas improved pastures still receive modest $\mathrm{P}$ fertilizer, and historically received higher application rates. Any current net import contributes to accumulation of $\mathrm{P}$ in pasture soils, which can cause increased nutrient loads (Capece et al. 2007). Therefore, it is important to understand whether net imports can be reduced or eliminated without hurting ranch production or economic performance.

We constructed $\mathrm{P}$ budgets for the experimental pastures by integrating information from cattle production, feed and mineral inputs, and exports of $\mathrm{P}$ in calves and surface runoff (Arthington et al. 2007; Capece et al. 2007). P inputs include mineral and molasses supplements $(6.0 \%$ for PDQ7 mineral; $0.65 \% \mathrm{P}$ for molasses) and rainfall (estimated using a value of 28 parts per billion $\mathrm{P}$ for rainfall in the region; US Environmental Protection Agency and South Florida Ecosystem Resto- ration Working Group 1999). P exports included P in calves shipped to market using standard values for P content of live cattle $(0.74 \%)$. Exports of $\mathrm{P}$ in surface runoff were taken from Capece et al. (2007). Estimates of P losses to groundwater are unknown but considered to be minimal relative to these other fluxes, because of the poorly drained status of soils at this site. $\mathrm{P}$ imports and exports for cattle were calculated for the entire land area (summer plus winter pasture) devoted to each experimental herd to simulate a combined year-round $\mathrm{P}$ budget for cattle in these small, simulated ranch systems (Table 3).

Overall, there was a greater net export of $\mathrm{P}$ from the experimental pastures at the high cattle stocking density than at the low or mid stocking density $\left(\mathrm{F}_{2,15}=7.04, P=0.007\right)$. The cattle operation resulted in a net export of $\mathrm{P}$ in all years at all cattle stocking densities, except in 2003 when there was a slight net import of $\mathrm{P}$ at the low and middle stocking densities (Table 3). Net export of $\mathrm{P}$ in calves tended to be greater in $1999-2000$ than from $2001-2003(\mathrm{~F}=2.73, P=0.07)$ mainly because greater amounts of molasses supplement were offered during the latter 3 years $(\mathrm{F}=4073.74, P<0.001)$.

Interannual variation in molasses inputs were because of differences among years in forage availability and weather and illustrate the importance of feed supplements to net imports or exports of $\mathrm{P}$ from the cattle operation. Weather conditions can lead to increased feed inputs for several reasons, including cold or freezing conditions that reduce forage availability, or unusually wet winter conditions induced by El Niño, which can increase stress on the cow herd during peak lactation. Interannual variation in runoff $\mathrm{P}$ is primarily because of differences in total rainfall and surface runoff among years.

Although our analysis showed that there was a net $\mathrm{P}$ export from the experimental pastures, other evidence suggests that there is a net import of $\mathrm{P}$ to pastures in the Okeechobee watershed (Hiscock at al. 2003). Using estimates of net $\mathrm{P}$ imports to improved pasture $\left(3.04 \mathrm{~kg} \cdot \mathrm{ha}^{-1} \cdot \mathrm{y}^{-1}\right)$ and seminative pasture or native rangeland $\left(0.01 \mathrm{~kg} \cdot \mathrm{ha}^{-1} \cdot \mathrm{y}^{-1}\right)$ from Hiscock et al. (2003), and applying these to the total area of land in these different pasture types, we calculated that there was an average net $\mathrm{P}$ import of $1.17 \mathrm{~kg} \cdot \mathrm{ha}^{-1} \cdot \mathrm{y}^{-1}$ to pastures in the Lake Okeechobee watershed. The difference between $\mathrm{P}$ budgets for the watershed and our experimental pastures may be because no $\mathrm{P}$ fertilizer was applied to the experimental pastures during the study period, whereas average $P$ fertilizer use on improved pastures throughout the watershed was estimated to be $5 \mathrm{~kg} \mathrm{P} \cdot \mathrm{ha}^{-1} \cdot \mathrm{y}^{-1}$ (Gornak and Zhang 1999).

When we estimated a P budget for the cattle operation on the entire Buck Island Ranch herd for the period 1994-2004 we found that there was an average net $P$ import of $0.30 \mathrm{~kg}$ $\mathrm{P} \cdot \mathrm{ha}^{-1} \cdot \mathrm{y}^{-1}$ (range: -0.12 to 0.75 ). The difference between the whole ranch and the experimental pastures in $\mathrm{P}$ importation was in part because of a higher percentage of calf crop for the small herds in the experimental pasture, which resulted in a greater export of $\mathrm{P}$ in calves. Any lost cows in the experimental pastures were replaced with a cow-calf pair to maintain stocking densities, which inflated $\mathrm{P}$ export in these calves relative to the whole ranch operation. The differences between the whole ranch and the experimental herds were not because of difference in stocking densities because the average ranch stocking rate $\left(\sim 0.70\right.$ animal unit $\left.[\mathrm{AU}] \cdot \mathrm{ha}^{-1}\right)$ was 
Table 3. Phosphorus (P) budget for the experimental pastures for 1999-2003 including imports in feed and rainfall and exports in calves and surface runoff in terms of total elemental $P$. Values are means \pm 1 standard deviation for 2 replicates of each stocking treatment.

\begin{tabular}{|c|c|c|c|c|c|c|c|c|c|}
\hline \multirow[b]{2}{*}{$\begin{array}{l}\text { Stocking } \\
\text { density }\end{array}$} & \multicolumn{3}{|c|}{ P imports } & \multicolumn{4}{|c|}{ P exports } & \multirow{2}{*}{$\begin{array}{l}\text { Net } P \text { export } \\
\text { from cattle } \\
\text { operation }^{2}\end{array}$} & \multirow{2}{*}{$\begin{array}{c}\text { Total net P } \\
\text { export (cattle } \\
\text { and runoff) }\end{array}$} \\
\hline & Minerals & Molasses & Rainfall & Calves & $\begin{array}{l}\text { Winter pasture } \\
\text { runoff }^{1}\end{array}$ & $\begin{array}{l}\text { Summer pasture } \\
\text { runoff }^{1}\end{array}$ & $\begin{array}{c}\text { Total surface } \\
\text { runoff }\end{array}$ & & \\
\hline & $-\cdots$ & 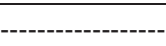 & & 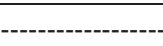 & - - & $a^{-1}$ & & & \\
\hline \multicolumn{10}{|c|}{ Year 1-1999 } \\
\hline Control & - & - & 0.32 & - & $0.12 \pm 0.06$ & $0.51 \pm 0.02$ & $0.27 \pm 0.04$ & - & $-0.05 \pm 0.04$ \\
\hline Low & $0.21 \pm 0.05$ & $0.36 \pm 0.00$ & 0.32 & $1.11 \pm 0.04$ & $0.12 \pm 0.03$ & $0.68 \pm 0.16$ & $0.38 \pm 0.08$ & $0.53 \pm 0.10$ & $0.59 \pm 0.18$ \\
\hline Middle & $0.17 \pm 0.03$ & $0.47 \pm 0.01$ & 0.32 & $1.52 \pm 0.10$ & $0.15 \pm 0.09$ & $1.01 \pm 0.30$ & $0.54 \pm 0.07$ & $0.88 \pm 0.13$ & $1.10 \pm 0.05$ \\
\hline High & $0.26 \pm 0.02$ & $0.92 \pm 0.02$ & 0.32 & $2.43 \pm 0.08$ & $0.13 \pm 0.04$ & $0.71 \pm 0.41$ & $0.39 \pm 0.15$ & $1.26 \pm 0.05$ & $1.34 \pm 0.10$ \\
\hline \multicolumn{10}{|c|}{ Year 2-2000 } \\
\hline Control & - & - & 0.21 & - & $0.05 \pm 0.01$ & $0.16 \pm 0.23$ & $0.09 \pm 0.08$ & - & $-0.12 \pm 0.08$ \\
\hline Low & $0.21 \pm 0.05$ & $0.36 \pm 0.00$ & 0.21 & $1.15 \pm 0.07$ & $0.06 \pm 0.02$ & $0.06 \pm 0.03$ & $0.06 \pm 0.03$ & $0.58 \pm 0.13$ & $0.43 \pm 0.10$ \\
\hline Middle & $0.17 \pm 0.03$ & $0.48 \pm 0.00$ & 0.21 & $1.47 \pm 0.14$ & $0.03 \pm 0.01$ & $0.09 \pm 0.17$ & $0.06 \pm 0.08$ & $0.82 \pm 0.17$ & $0.67 \pm 0.10$ \\
\hline High & $0.26 \pm 0.02$ & $0.84 \pm 0.00$ & 0.21 & $2.38 \pm 0.57$ & $0.09 \pm 0.03$ & $0.04 \pm 0.05$ & $0.07 \pm 0.04$ & $1.30 \pm 0.55$ & $1.14 \pm 0.51$ \\
\hline \multicolumn{10}{|c|}{ Year 3-2001 } \\
\hline Control & - & - & 0.36 & - & $0.61 \pm 0.38$ & $3.84 \pm 0.81$ & $1.87 \pm 0.09$ & - & $1.51 \pm 0.09$ \\
\hline Low & $0.16 \pm 0.02$ & $0.79 \pm 0.00$ & 0.36 & $1.15 \pm 0.04$ & $0.45 \pm 0.31$ & $4.30 \pm 0.08$ & $1.92 \pm 0.16$ & $0.20 \pm 0.02$ & $1.76 \pm 0.15$ \\
\hline Middle & $0.25 \pm 0.12$ & $1.02 \pm 0.00$ & 0.36 & $1.38 \pm 0.19$ & $0.32 \pm 0.16$ & $3.27 \pm 0.28$ & $1.44 \pm 0.02$ & $0.11 \pm 0.07$ & $1.19 \pm 0.05$ \\
\hline High & $0.31 \pm 0.10$ & $1.52 \pm 0.00$ & 0.36 & $2.14 \pm 0.31$ & $0.64 \pm 0.03$ & $3.45 \pm 1.07$ & $1.72 \pm 0.43$ & $0.32 \pm 0.42$ & $1.68 \pm 0.01$ \\
\hline \multicolumn{10}{|c|}{ Year 4-2002 } \\
\hline Control & - & - & 0.44 & - & $0.42 \pm 0.14$ & $3.50 \pm 0.74$ & $1.60 \pm 0.37$ & - & $1.16 \pm 0.37$ \\
\hline Low & $0.29 \pm 0.01$ & $0.59 \pm 0.00$ & 0.44 & $1.21 \pm 0.04$ & $0.28 \pm 0.16$ & $3.08 \pm 0.17$ & $1.36 \pm 0.04$ & $0.33 \pm 0.03$ & $1.25 \pm 0.07$ \\
\hline Middle & $0.40 \pm 0.14$ & $0.79 \pm 0.00$ & 0.44 & $1.50 \pm 0.37$ & $0.34 \pm 0.24$ & $3.72 \pm 1.87$ & $1.64 \pm 0.57$ & $0.31 \pm 0.51$ & $1.51 \pm 0.06$ \\
\hline High & $0.66 \pm 0.00$ & $1.38 \pm 0.00$ & 0.44 & $2.71 \pm 0.02$ & $0.50 \pm 0.30$ & $2.82 \pm 1.01$ & $1.39 \pm 0.57$ & $0.67 \pm 0.02$ & $1.62 \pm 0.55$ \\
\hline \multicolumn{10}{|c|}{ Year 5-2003 } \\
\hline Control & - & - & 0.39 & - & $0.15 \pm 0.08$ & $1.41 \pm 0.30$ & $0.64 \pm 0.16$ & - & $0.25 \pm 0.16$ \\
\hline Low & $0.30 \pm 0.02$ & $0.91 \pm 0.00$ & 0.39 & $0.99 \pm 0.02$ & $0.11 \pm 0.06$ & $1.27 \pm 0.11$ & $0.56 \pm 0.03$ & $-0.22 \pm 0.00$ & $-0.05 \pm 0.03$ \\
\hline Middle & $0.30 \pm 0.05$ & $1.08 \pm 0.00$ & 0.39 & $1.33 \pm 0.44$ & $0.14 \pm 0.10$ & $1.50 \pm 0.76$ & $0.66 \pm 0.23$ & $-0.05 \pm 0.49$ & $0.23 \pm 0.26$ \\
\hline High & $0.37 \pm 0.05$ & $1.65 \pm 0.00$ & 0.39 & $2.16 \pm 0.22$ & $0.20 \pm 0.12$ & $1.14 \pm 0.41$ & $0.56 \pm 0.23$ & $0.13 \pm 0.27$ & $0.31 \pm 0.04$ \\
\hline
\end{tabular}

${ }^{1}$ Data from Capece et al. (2007).

${ }^{2}$ Cattle net $\mathrm{P}$ export is calculated as (calves) - (mineral + molasses).

${ }^{3}$ Total net $\mathrm{P}$ export is calculated as (calves + total surface runoff $)-($ mineral + molasses + rainfall).

actually slightly higher than the high stocking density treatment (0.67 $\mathrm{AU} \cdot \mathrm{ha}^{-1}$ in the combined summer and winter experimental pastures) and thus would be expected to have equal or higher P export. The estimated P budget for the whole of Buck Island Ranch cattle operations did not include other significant flows of $\mathrm{P}$ that occur on this or other ranches regionally, such as those involved in citrus or sod production, which would be necessary to calculate a complete $\mathrm{P}$ budget for the whole ranch system. However, the whole ranch analysis for just the cattle operation indicates, contrary to results from the experimental pastures, that significant adjustments to current practices would be needed to achieve net $\mathrm{P}$ export, or even $\mathrm{P}$ balance, for the cattle operation on a whole ranch scale.

\section{Achieving Economic and Environmental Sustainability of Ranches}

Sustainable management of beef cattle ranches at economically viable stocking rates appears to be compatible with legislative mandates to lower nutrient loads into Lake Okeechobee. This conclusion assumes that "economically sustainable" means sustaining the current rates of financial return, broadly representative of the region. It certainly does not take into account other influences, such as real estate development pressures facing Florida cattle ranches.

Environmental sustainability of ranches in this region will hinge to a great extent on their role in regional efforts to manage the supply and quality of water, and their conservation benefits for wildlife habitat and biodiversity. The main focus of this experiment was on P loads in surface runoff, which remains a significant concern of state and federal regulatory agencies. The P budget estimates for Buck Island Ranch suggest that cattle operations likely contribute to net $\mathrm{P}$ import to the Okeechobee watershed. Continued imports of P and the legacy effects of $\mathrm{P}$ from previous fertilizer use create a challenge for bringing ranches into $\mathrm{P}$ balance, especially if there is further intensification of ranch operations. However, the net import of $\mathrm{P}$ observed for the cattle ranches in the Lake Okeechobee watershed is far lower than for nearly all other land uses, which is one reason why cattle ranches have a prominent role in 
regional water quality planning initiatives (Hazen and Sawyer 2002, 2003; Hiscock et al. 2003).

Beef cattle ranches are the most extensive land use in the Lake Okeechobee watershed and are less intensively managed than many alternative land uses, such as citrus, dairy, and field crops, or urban development. In the past 10-15 years there has been a slight increase in the amount of improved pasture in the watershed and a large reduction in the amount of rangeland $(74,000$ ha down to 46,641 ha) and seminative pasture $(62,000$ ha down to 33,453 ha) (Hiscock et al. 2003). Total net import of $P$ to improved pastures, which is because of continued use of P fertilizer on some pastures (Gornak and Zhang 1999) as well as supplementary feed, remains the single largest net import of $\mathrm{P}$ to the Lake Okeechobee watershed, because of the extensive area of improved pasture in the watershed (183,778 ha) (Hiscock et al. 2003). Continued conversion of rangeland and seminative pasture on ranches to more intensive pasture or other intensive land uses will detract from the potential of these less-intensively managed grazing lands to maintain the region's water quality and enhance its biodiversity.

Any attempts to manage cattle pastures for reduced nutrient loads will need to take into account the legacy of past $\mathrm{P}$ fertilizer use. High P loads in runoff from improved pastures occurred in spite of the fact that these pastures had not received $\mathrm{P}$ fertilizer since 1987. If the recommended rate of $45 \mathrm{~kg}$ $\mathrm{P}_{2} \mathrm{O}_{5} \cdot \mathrm{ha}^{-1} \cdot \mathrm{y}^{-1}\left(\sim 20 \mathrm{~kg} \mathrm{P} \cdot \mathrm{ha}^{-1} \cdot \mathrm{y}^{-1}\right)$ was applied to the improved pastures in our study over a period of 15-20 years, then the cumulative amount of $\mathrm{P}$ added would have been 295 $393 \mathrm{~kg} \mathrm{P} \cdot \mathrm{ha}^{-1}$. Assuming that there was a net $\mathrm{P}$ retention of $74 \%$ (based on estimates for the Okeechobee watershed; Hiscock et al. 2003), then a total of 203-271 kg P $\cdot \mathrm{ha}^{-1}$ may have accumulated in improved pasture soils prior to 1987, when $\mathrm{P}$ fertilizer use was discontinued because of changes in fertilizer recommendations for Bahia grass. If these assumptions about $\mathrm{P}$ accumulation in pasture soils are correct, the amount of $\mathrm{P}$ currently exported in surface runoff $(\sim 1-2 \mathrm{~kg}$ $\left.\mathrm{P} \cdot \mathrm{ha}^{-1} \cdot \mathrm{y}^{-1}\right)$ and calves $\left(\sim 1 \mathrm{~kg} \cdot \mathrm{ha}^{-1} \cdot-\mathrm{y}^{-1}\right)$ annually is about $1 \%$ of the original amount of accumulated P. As discussed above, net export of $\mathrm{P}$ in calves may not occur under normal ranch practices. Furthermore, we do not know whether the $\mathrm{P}$ loss in runoff has declined since 1987 and, if it has declined, we do not know the rate of change through time or whether it will achieve a lower equilibrium level over the long term with no new $P$ fertilizer inputs.

Current collaborative efforts are underway in the watershed for ranchers to adopt, voluntarily, water quality BMPs outlined in the FCA Manual (FCA 1999). Although ranchers who adopt the BMP program are given a presumption of compliance with water quality standards, there are few data to quantify the effectiveness of most BMPs at reducing P loads, and thus there is a great deal of uncertainty in forecasting their cumulative effectiveness. A recent economic analysis concluded that of 11 P-control alternatives to reduce P loadings into Lake Okeechobee, enhancing beef cow-calf BMPs was the most effective, scoring well under all assessment criteria, although confidence in the probability of success is lower because of limited data on BMP effectiveness (Hazen and Sawyer 2002, 2003). There is a need for more research on the performance of cow-calf BMPs, including practices that slow or eliminate off-site drainage (Hazen and Sawyer 2002, 2003).
The mandate to reduce $\mathrm{P}$ loads into Lake Okeechobee will continue to be the primary environmental concern affecting cattle ranchers in this region. Regional plans to protect the lake's water quality include goals for improving wildlife habitat, restoring degraded wetlands, and minimizing economic impact to private landowners in the watershed. Although our project included analysis of soil nematode communities and general bird surveys, more information on biological communities on ranches is needed to assess the contribution of ranches to regional biodiversity, a subject that has received less attention than the prominent water quality issues. Achieving these goals will require continued collaborative efforts between state agencies, researchers, and producers and will depend upon integrative research approaches, such as this one, that evaluate the impact of proposed solutions upon these multiple goals.

\section{ACKNOWLEDGMENTS}

We would like to acknowledge all the institutions and their institutional representatives that were part of the 1996 memorandum of understanding for helping to fund and manage this project including the following: P. Werner, S. Rao, and E. Hanlon from UF-IFAS; J. Schaefer and N. Peterson from the University of Florida Center for Natural Resources; N. Aumen, S. Gray, B. Whalen, and O. Villapando of the South Florida Ecosystem Restoration Working Group; R. Budell and C. Aller of the Florida Department of Agriculture and Consumer Services; K. Shugar and T. Azziz from the Florida Department of Environmental Protection; and the Florida Cattlemen's Association. The USDA-NRCS gave technical assistance and advice throughout. Numerous research staff and cowboys at MAERC provided field and lab support, especially the research assistants: D. Buchanan, L. Collins, M. Ferree, S. Harris, A. Bubb, G. Huey, D. Ingall, J. Rodriguez, and L. Rojas; R. Pickert of Archbold Biological Station provided GIS support. Finally we acknowledge the other ranchers, researchers, and agency staff who helped with this project.

\section{LITERATURE CITED}

Arthington, J. D., F. M. Roka, J. J. Mullahey, S. W. Coleman, R. M. Muchovej, L. 0. LOLLIS, AND D. HITCHCOCK. 2007. Integrating ranch forage production, cattle performance, and economics in ranch management systems for southern Florida. Rangeland Ecology and Management 60:12-18.

Aumen, N. G. 1995. The history of human impacts, lake management, and limnological research on Lake Okeechobee, Florida (USA). Archiv für Hydrobiologie-Beiheft Ergebnisse der Limnologie 45:1-16.

Bennett, E. M., S. R. Carpenter, and N. F. Caraco. 2001. Human impact on erodable phosphorus and eutrophication: a global perspective. BioScience 51: 227-234.

Capece, J. C., K. L. Campbell, P. J. Bohlen, D. A. Graetz and K. M. Portier. 2007. Soil phosphorus, cattle stocking rates, and water quality in subtropical pastures in Florida, USA. Rangeland Ecology and Management 60:19-30.

Carpenter, S. R., N. F. Caraco, D. L. Correll, R. W. Howarth, A. N. Sharpley, and V. H. Smith. 1998. Nonpoint pollution of surface waters with phosphorus and nitrogen. Ecological Applications 8:559-568.

Carroll, C. R., J. H. Vandermeer, and P. Rosset. 1990. Agroecology. New York, NY: McGraw-Hill. 641 p.

Cox, J., R. Kautz, M. Maclaughlin, and T. Gilbert. 1994. Closing the gaps in Florida's wildlife habitat conservation system. Tallahassee, FL: Florida Game and Fresh Water Fish Commission. 239 p.

DeAngelis, D. L., L. J. Gross, M. A. Huston, W. F. Wolff, D. M. Fleming, E. J. ComiskeY, AND S. M. Sylvester. 1997. Landscape modeling for Everglades ecosystem restoration. Ecosystems 1:64-75. 
Emmerich, W. E., and R. K. Heitschmidt. 2002. Drought and grazing: ii. effects on runoff water quality. Journal of Range Management 22:229-234.

Florida Cattlemen's Association. 1999. Water quality best management practices for cow/calf operations in Florida. Kissimmee, FL: Florida Cattlemen's Association. $64 \mathrm{p}$.

Gillen, R. L., J. A. Eckroat, and F. T. McCollum III. 2000. Vegetation response to stocking rate in southern mixed-grass prairie. Journal of Range Management 53:471-478.

Gliessman, S. R. 1990. Agroecology: Researching the ecological basis for sustainable agriculture. New York, NY: Springer-Verlag. 380 p.

GoRnak, S., AND J. ZHANG. 1999. A summary of landowner surveys and water quality data from improved pasture sites in the northern Lake Okeechobee watershed. Applied Engineering in Agriculture 15:121-127.

Hart, R. H., M. J. Samuel, P. S. Test, and M. A. Smith. 1988. Cattle, vegetation, and economic responses to grazing systems and grazing pressure. Journal of Range Management 41:282-286.

HARWELL, M. A. 1998. Science and environmental decision making in South Florida. Ecological Application. 8:580-590.

Havens, K. E., AND C. L. Schelske. 2001. The importance of considering biological processes when settling total maximum daily loads (TMDL) for phosphorus in shallow lakes and reservoirs. Environmental Pollution 113:1-9.

Hazen AND SAwyer 2002. Natural resource analysis of Lake Okeechobee phosphorus management strategies. Contract C-11677. Phase I. Documentation report prepared for the South Florida Water Management District. West Palm Beach, FL: Hazen and Sawyer Environmental Engineers and Scientists. 342 p.

Hazen And SAwyer 2003. Natural resource analysis of Lake Okeechobee phosphorus management strategies. Contract C-11677. Phase II summary report. Prepared for the South Florida Water Management District. West Palm Beach, FL: Hazen and Sawyer Environmental Engineers and Scientists. 492 p.

Heitschmidt, R. K., S. L. Dowhower, W. E. Pinchak, and S. K. Canon. 1989. Effects of stocking rate on quantity and quality of available forage in a southern mixed grass prairie. Journal of Range Management 42:468-473.

Hiscock, J. G., C. S. Thourot, And J. Zhang. 2003. Phosphorus budget analysis relating to land use for the northern Lake Okeechobee watershed, Florida. Environmental Engineering 21:63-74.

Mapfumo, E., W. D. Willms, and D. S. Chanasyk. 2002. Water quality of surface runoff from grazed fescue grassland watersheds in Alberta. Water Quality Research Journal of Canada 37:543-562.

McCollum, F. T., III, R. L. Gillen, B. R. Karges, and M. E. Hodges. 1999. Stocker cattle response to grazing management in tallgrass prairie. Journal of Range Management 52:120-126.

McGrann, J. M., R. Jones, and D. McCorkle. 2001. Cow-calf enterprise standardized performance analysis (SPA). Texas Agricultural Extension Service Publication L-5355. College Station, TX: Texas Cooperative Extension, Texas A\&M University. 4 p. Available at http://tcebookstore.org/tmppdfs/ 15149155-L5355.pdf. Accessed 8 December 2006.

McSorley, R., AND G. W. TANner. 2007. Effects of cattle stocking rates on nematode communities in south Florida. Rangeland Ecology and Management 60:31-35.

Sharpley, A. N., S. C. Chapra, R. Wedepohl, J. T. Sims, T. C. Daniel, and K. R. Reddy. 1994. Managing agricultural phosphorus for protection of surface waters: issues and options. Journal of Environmental Quality 23:437-451.

South Florida Water Management District. 1997. Surface water improvement and management (SWIM) plan—Update for Lake Okeechobee: Volume 1. Planning document. West Palm Beach, FL: South Florida Water Management District. $181 \mathrm{p}$.

South Florida Water Management District. 2004a. Lake Okeechobee protection program: Lake Okeechobee protection plan. West Palm Beach, FL: South Florida Water Management District, Florida Department of Environmental Protection, Florida Department of Agriculture and Consumer Services. 83 p.

South Florida Water Management District. 2004b. Comprehensive Everglades restoration program annual report. West Palm Beach, FL: South Florida Water Management District and Florida Department of Environmental Protection. $108 p$.

Steinman, A. D, K. E. Havens, N. Aumen, N., R. T. James, K. Jin, J. Zhang, and B. Rosen. 1999. Phosphorus in Lake Okeechobee: sources, sinks and strategies. In: K. Reddy, G. O'Connor, and C. Schelske [EDS.]. Phosphorus biogeochemistry of subtropical ecosystems: Florida as a case example. Boca Raton, FL: CRC Press. p 527-544.

Swain, H. M. 1998. Archbold Biological Station and the MacArthur Agro-ecology Research Center. Bulletin of the Ecological Society of America 79:114-120.

Taylor, C. A., JR., M. E. Ralphs, and M. M. Kothmann. 1997. Vegetation response to increasing stocking rate under rotational stocking. Journal of Range Management 50:439-442.

Teague, W. R. 1996. A research framework to achieve sustainable use of rangeland. Agriculture Ecosystems and Environment 57:91-102.

us Department of Agriculture-National Agricultural Statistics Service. 2006. Cattle inventory, January 1, 2006: cows that calved-beef. Washington, DC: National Agricultural Statistics Service, Agricultural Statistics Board, US Department of Agriculture. Available at http://www.nass.usda.gov:8080/ QuickStats/PullData_US.jsp. Accessed 5 October 2006.

us Environmental Protection Agency and South Florida Ecosystem Restoration Working Group. 1999. Lake Okeechobee Action Plan. South Florida Ecosystem Restoration Working Group. West Palm Beach, FL: US Environmental Protection Agency and South Florida Water Management District. 43 p. 